\title{
A Study on the Directions of Regional Planning for Village Renewal in Korea
}

\author{
Im, Sang-Bong \\ Rural Research Institute, KRC

\section{마을 재개발을 위한 지역계획수립 방향에 관한 연구} \\ 임상봉 \\ 한국농어촌공사 농어촌연구원
}

\begin{abstract}
요약 : 이 연구의 목적은 지자체의 계획수립 정책과 마을주민의 요구를 분석하여 농촌마을 재개발을 위한 지역계획 방향을 제시하는 데 있다. 마을재개발 주요 내용으로는 생활편의성 향상 뿐만 아니라 자연환경, 역사문화와 같은 어메니티 자원과 경관자원 등의 보전과 활용이 포함되어야 한다는 관점을 취하였다. 마을주민에 대한 설문조사와 마을재개발 계획수립 과정 및 결과에 분석을 토대로, 농촌마을재개발 계획의 특징을 파악한 후, 향후 발전을 위한 과제를 다음과 같이 제시하였다. 첫째, 마을재개발시 국토이용계획과 농촌특성을 반영할 수 있도록 토지이용 및 농촌개발 관련법을 보완해야 한다. 둘째, 농 촌지역에 주거 및 취락지구를 도입하여 체계적인 마을정비가 이루어질 수 있도록 유도해 나갈 필요가 있다. 셋째, 지역계 획수립 체계를 토지이용계획과 마을재개발 추진에 적합한 형태로 확립, 운영토록 한다. 넷째, 마을개발 부지 확보를 원활하 게 할 수 있는 방향으로 농지교환분합 제도를 활성화해 나가도록 한다. 다섯째, 지역계획과 마을재개발이 유기적으로 연계 되어 추진될 수 있도록 우선 개발 마을을 선정하고, 마을주민의 요구를 반영한 마을발전계획을 수립하며, 농촌취락지구와 같은 농촌토지 용도지구를 도입, 운영할 필요가 있다. 여섯째, 마을재개발 시범사업의 추진 및 평가를 토대로 체계적인 본 사업을 확대, 시행해 나가는 방안 마련이 필요하다. 일곱째, 농촌지역의 낙후도를 고려한 사업지원 및 추진에 차등화 방안 을 마련할 필요가 있다.
\end{abstract}

Key words : Regional Planning Policy, Village Renewal

\section{Introduction}

In the era of globalization, rural development has become a great concern in many countries in order to (1) conserve the natural environment, and (2) narrow gaps in regional disparities(Dammers and Keiner, 2006). Public investment in rural development aims at both, competitiveness and sustainability. In this context, some the following questions have to be raised: Why is village renewal urgently needed in Korea? What is the theoretical basis? And, what should be the directions of regional planning for the village renewal? It seems that theoretical

Corresponding Author: Im, Sang-Bong

Tel : 031-400-1766

E-mail : imsb@ekr.or.kr logics and remedial measures still lack in regional planning for sustainable rural development.

In the process of the urban-centered and rapid industrialization, Korean rural area is characterized by depopulation and an ageing society. The rural population has dramatically decreased from $58.8 \%$ in 1970 to $18.0 \%$ in 2010. The ratio of people aged 65 or more in total rural population reached $21.7 \%$ in 2000. Such social changes have weakened rural sustainability in that social service costs increase and business and commercial demands decrease.

Migration of urban citizens to rural areas has been one of the key factors for rural revitalization as a result of counter-urbanization(Roberts 2002). Thus, sustainability of rural areas is required not only for rural people but also 
for urban citizens(Heins 2004, Morimoto 2004). The rural areas can provide places to live and work for rural and exurban people. They also give places for leisure, sports, recreation and tourism to visitors as well as dwellers. While rural areas are getting closer to applying planning mechanisms, they are still unsystematically arranged in that there is lack of specific formal planning procedures and documents. Villages play key roles in managing and developing rural areas sustainably. Rural areas are considered important because they are home to vital natural resources including fresh water production; natural habitats and areas for agricultural production.

With this in mind, rural policy is drafted to effectively ensure sustainable rural development(Terluin et al., 2006). In this context rural development planning has been instrumental in narrowing the gap of service provision and perceived quality of life between urban and rural areas. However, investments aimed at reducing regional disparities have externalities(OECD, 1999). Regional planning can be a good instrument to deal with these externalities through the change of rural land use and the increase of public investment such as roads, sewage system for attracting people to live. Therefore, the regional planning for village renewal will have to deal with such sustainability and publicity issues in an effective manner.

During the modernization era, Korea's rural settlements have been neglected due to the lack of investment. Since "'Saemaul Undong"' was initiated in 1970, a lack of systematic actions for village restructuring - except for some pilot projects - is evident. With the rise of environmental concern, rural areas are currently being newly re-assessed. Examples are the recognition of the value of the natural environment as a public goods and rural tourism development based on natural environments and landscapes(OECD, 1999; Anton, 2005). However, it seems that Korea's regional planning system has lagged in accommodating such trends. Moreover, it seems that there is no clear linkage between the regional development planning system, rural development and the village renewal program.

In this context the objectives of this study are to analyze local planning policy on the one hand, and local needs on the other hand - with a view to craft suggestions for the further development of regional planning for rural village renewal. Emphasis has been placed on the preservation and utilization of endowed resources, such as natural and cultural amenities, and landscapes, as well as the improvement of the living environment for rural residents. In addition to secondary data and document analysis, a questionnaire was distributed to village inhabitants and leaders in the Gyeongbuk province.

Based on the above survey and analysis of the village renewal planning process and related planning documents, as well as project implementation, major characteristics and trends of rural village renewal planning are identified and tasks for future development are suggested. The results of this study not only strive to facilitate balanced regional development in Korea, but also aim to provide useful information for developing countries, pursuing sustainable rural development.

\section{Theoretical framework for regional planning and rural development}

\section{1) Characteristics and principles of regional planning}

Compared to urban planning, regional planning for rural areas deals with relatively low development density and a larger area. Theoretically, a region comprises one or more urban centers and the related hinterland. Thus, regional planning puts an emphasis on a broader and more generalized approach It takes into consideration the area's topography and existing settlement pattern and generally involves spatial planning, land use zoning, infrastructure planning and environmental preservation as well as agricultural and tourism planning(OECD, 1999).

This study developed new model for regional planning process as shown in Figure 1. It explains that sustainable urban, regional and rural development can be achieved through the mediating, integrating and harmonizing functions of regional planning.

Rural development needs to be implemented within the regional planning framework. It will be an important task, not only to catch up with such advanced experiences as endogenous growth through utilization of endowed resources, spatial development considering economic geography, but also to create a new source of innovations in a given regional condition(Dunford, 2008). 
In regional planning for rural development, conflicts between private and public interests may occur with regard to land use and the related economic, social and environmental implications. Some tensions are intrinsic in making use of rural resources, such as forests lands, which have both an ecological value and an economic value, and also contribute to defining an area's rural character(OECD, 1999). These conflicts need to be managed and resolved. Possible solutions may include - amongst other things public investment for rural development within a stable legal system and land use regulations as well as effective public participation in the planning process. Public policy goals, such as rural economic diversification, agricultural restructuring and environmental conservation, regularly require public interventions - including regional planning.

The results of the literature review - conducted as part of this study - indicate the following success factors of regional planning:

- Addressing all major elements of regional planning, including "development policies and goals," "land use," 'housing and public infrastructure," "agricultural, natural and cultural resources," "economic development," "participation of stakeholders,"(Ohm, 2001);

- Establishing goals for efficiency of the planning process, regional competitiveness, and sustainability;

- Pursuing approaches that are integrated, cooperative,
$<$ Characteristics of Unban and Rural Areas>

\begin{tabular}{|l|}
\hline Urban Areas \\
Main Strengths \\
- Economy of scale \\
- Agglomeration economies \\
Main Weaknesses \\
- Environmental pollution \\
- Over-crowding and congestion \\
- Externality - e.g. impact on \\
hinterland ind of major infrastructure \\
- impact of - \\
projects on hinterland (e.g. power, \\
waste treatment, transport etc. - \\
benefit urban areas but mainly impact \\
on rural areas
\end{tabular}

$<$ Public Interventions $>$

$<$ Desired Outcomes $>$

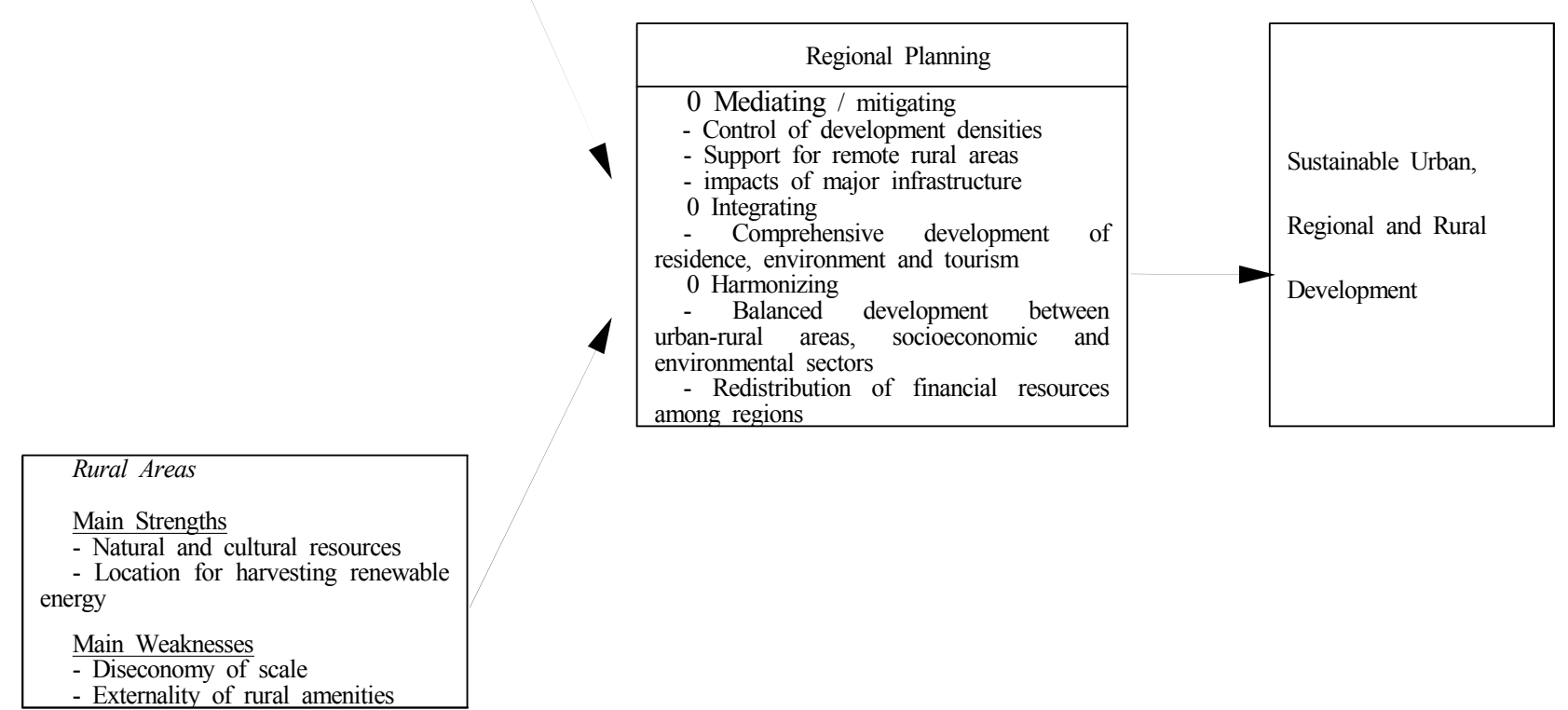

Figure 1 A model for regional planning setting a framework for sustainable rural planning and development. 
voluntary, and participatory(Pal, 2008; Waterhout, 2008);

- Combining action plans with incentive systems; and

- Selecting key indicators of sustainable development such as water quality, agricultural restructuring, population, employment and income increase, and improvements to living environment(Kates et al., 2005; U.S. Interagency Working Group on Sustainable Development Indicators Washington D.C., 2001).

\section{2) Rural development and village renewal model}

Rural development can be defined as the improvement of economic, social and environmental aspects through efficient use and management of endowed resources. As rural development and planning are closely related to urban development, the latter always needs to be considered(Hite, 1999). In this context worldwide trends are: to pursue agricultural and industrial competitiveness, to develop and/or preserve attractive living and recreational environments, as well as environmentally-friendly and sustainable places in rural areas(WWF, LUPG and SNM, 2005).

In addition, rural development regularly requires strong public intervention. Agriculture and rural areas need to be appreciated for their multi-functionality, especially their ecological and landscape aspects(Jervell and Jolly, 2003; Doitchinova, 2005). As mentioned above efficiency is considered an important factor in the process of planning and linked public investment - for rural development. It is expected that systematic implementation based on laws, regulations and policies helps to ensure the desired effectiveness and efficiency in rural development. Thus, it is becoming important more and more to develop appropriate policies and regulations in order to prioritize the development of rural areas based on their spatial and other intrinsic characteristics. This study suggests a model for sustainable rural planning and development as shown in Figure 2.

Villages can play a key role to develop rural areas. It seems that they are regarded as the 'hearts' of rural areas in which various kinds of socio-economic and cultural activities take place. Thus, village development or renewal will have an important role in the process of rural development. Figure 3 shows a theoretical model of the rural village renewal process and outcomes. It sees village renewal as a stimulus factor for sustainable rural development. Such rural development may be achieved by utilizing existing resources in a close relationship with urban areas(Nemes, 2005). Here, village renewal is more emphasized than new development of in that demographic shrinkage requires restructuring and qualitative development rather than quantitative expansion, protection of greenfield land, positive aspects/synergies such as use of existing social and cultural infrastructure.

Village renewal has been emphasized especially in Germany and other European Union countries since the 1970s(Magel, 2008). It has been closely related to the change in the structure of agriculture and villages(Magel, 2008). The focus of renewal programs has moved from initially sector-oriented agrarian policy to the integration of general policies for economic, spatial and, environmental planning(Magel, 2008).

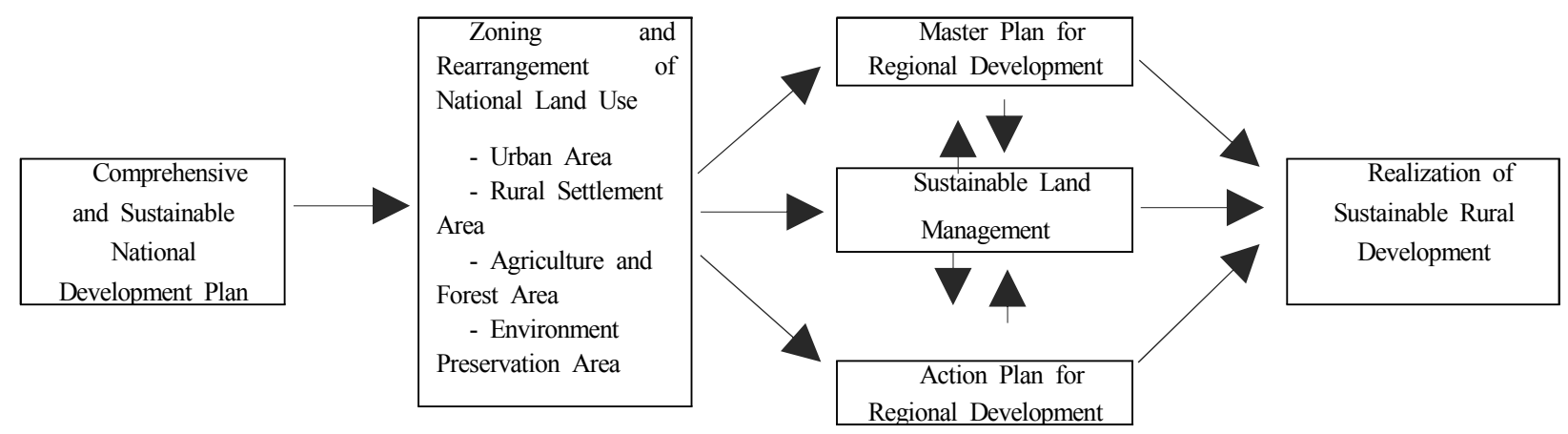

Figure 2 A model for sustainable rural development. 


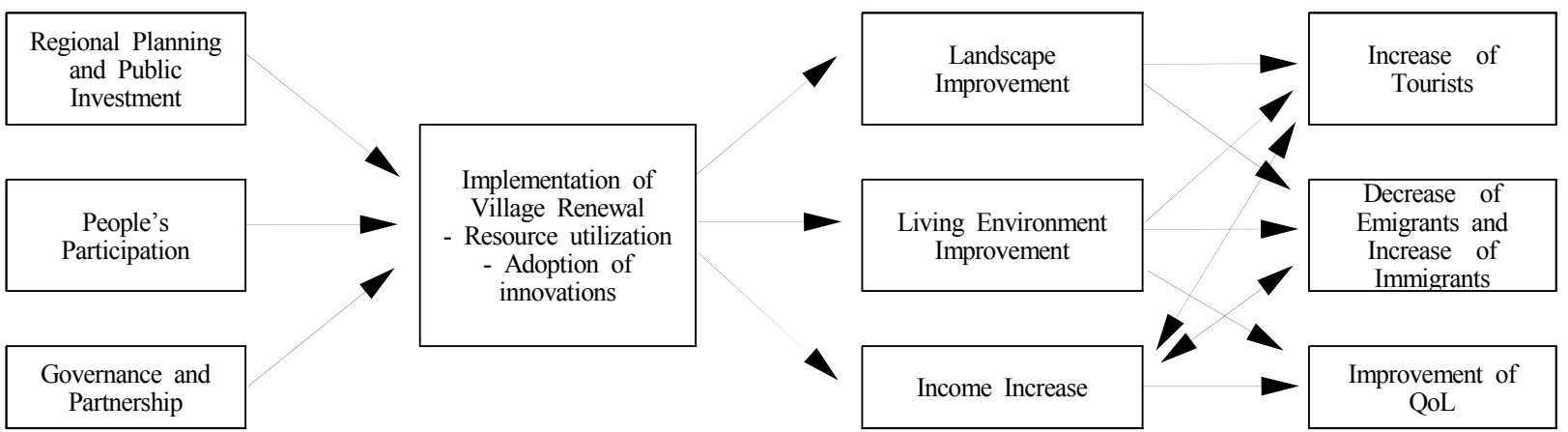

Figure 3 A theoretical model of rural village renewal process and outcomes.

The State of Bavaria in Germany serves as a good example for village renewal(Bavarian State Ministry for Agriculture and Forestry, 2003). It shows that rural areas can be sustainably developed by linking spatial planning with landscape management, environment conservation, organic farming, improving the built environment, and creating recreation areas. Because of the positive rural development experiences the renewal of villages and landscape management are currently focal areas of spatial planning. In this context land consolidation and improvement of public facilities traditionally have been considered important measures for rural development (Bavarian State Ministry for Agriculture and Forestry, 2003). In Korea's case, it seems that lessons can be learned from these European experiences with a view to further improve village renewal in an integrated regional planning process.

\section{Review of Korea's regional planning and village development system}

\section{1) Regional planning system}

There are various regional and rural development plans in Korea. Examples include: Special Area Development Plan; Province Development Master Plan; City and County Master Plan; City and County Management Plan; and Farmland Use Plan. They are basically developed within the framework provided by the legal system and the national land use plan. The plan regulates regional zoning, including such as urban, managerial - which takes high pressure on urban expansion, governance, agriculture and forestry, natural environment conservation zones, as shown in Table 1. Development densities and activities are controlled by the zoning system.

To date the main role of Korea's regional planning system has been the control of development densities through the national land use zones rather than providing a comprehensive master plan and action plans for sustainable regional development. Although the national law is supposed to provide a framework for the entire country, it seems that it does not give specific guidelines for rural areas because it is very much focused on urban planning. According to the law, most of the rural areas belong to

Table 1 Classification of national land use zones(2010)

\begin{tabular}{c|c|c|c|c|c}
\hline Classification & Total & Urban Zone & Managerial Zone & $\begin{array}{c}\text { Agriculture \& } \\
\text { Forestry Zone }\end{array}$ & $\begin{array}{c}\text { Natural Environment } \\
\text { Conservation Zone }\end{array}$ \\
\hline Area (sq. km) & 105,522 & 17,492 & 25,824 & 50,481 & 11,725 \\
\hline$\%$ & 100.0 & 16.6 & 24.5 & 47.8 & 11.1 \\
\hline
\end{tabular}

Source: Ministry of Land, Infrastructure, and Transportation. 2011. Annual Report on National Land Use. 
the so called "agriculture and forestry zone." And there is no specific land use classification for rural development, such as rural settlement areas. In addition, in the regional development plan, the natural environment conservation zone, defined in spatial planning documents and mostly located in rural areas, has no close relationship with ecological or landscape improvement activities set out in sectoral planning policies.

The economic development and management of rural areas is also based on the Rural Development Act. A structural fund has been created for rural development based upon this Act. However, there is no systematic regional development plan for the effective allocation of such funds with a view to use natural resources for diversification and income generation in rural areas, as shown in Figure 1, 2 and 3. As a consequence the system does not ensure the postulated effectiveness and efficiency. With regard to the current regional development and planning system, it seems that more active interaction among urban planning, natural environment improvement and rural development is required.

\section{2) Major characteristics of rural areas}

According to the national statistics, about 36,000 villages exist in Korea. The number of rural villages has been relatively stable although the rural population has sharply decreased, as shown in Table 2, since industrialization and urbanization have occurred. As a consequence of this demographic decline there are many very small villages with potentially only a few households per village - or hamlet, which bring such as abandoned buildings, infrastructure, former agricultural land no longer cultivated. Thus, it implies that it is important to prioritize the development of some "'key villages"".

Considering the large proportion of the country which is designated as rural, which comprises $89.8 \%$ of whole country, rural planning and village development should be more of a priority.

The average area of farmland per household is still very small, although an agricultural restructuring program has been carried out since 1992, as shown in Table 3. Villagers have lacked opportunities to raise their income levels. In this context it also seems practical to link agricultural restructuring to rural tourism, thereby coordinating these sometimes conflicting land uses in rural areas. This in turn could be facilitated by performing regional and countryside planning in harmony with environmental conservation and by introducing a village renewal program integrated with or alongside the existing structural funds.

\section{3) Village development and renewal program}

Modernization of rural villages has been carried out by means of a so called "'new village construction program"' by the Korea Rural Community Corporation(KRC), a government-funded agency, since 1992. It aims to revitalize rural areas, which had been stagnant after the "'Saemaul Undong'". However, the rural village modernization program has had little influence on existing villages because only a limited number of projects has been

Table 2 Ratio of urbanization in Korea.

\begin{tabular}{c|c|c|c|c|c|c|c|c|c|c|c}
\hline Year & 1960 & 1965 & 1970 & 1975 & 1980 & 1985 & 1990 & 1995 & 2000 & 2005 & 2010 \\
\hline \hline $\begin{array}{c}\text { Urbanization } \\
\text { ratio }\end{array}$ & 28.0 & 33.5 & 41.2 & 48.4 & 57.3 & 65.4 & 74.4 & 78.5 & 79.7 & 81.5 & 82.0 \\
\hline
\end{tabular}

Source: http:/www.kosis.kr/

Table 3 Average farmland size per household in Korea

(Unit: ha; 1,000 households)

\begin{tabular}{l|c|c|c|c|c|c|c|c|c}
\hline \multicolumn{1}{c|}{ Classification } & 1970 & 1975 & 1980 & 1985 & 1990 & 1995 & 2000 & 2005 & 2010 \\
\hline \hline Average farm size & 0.93 & 0.94 & 1.02 & 1.11 & 1.19 & 1.32 & 1.37 & 1.43 & 1.46 \\
\hline $\begin{array}{l}\text { Number of farm } \\
\text { households }\end{array}$ & 2,483 & 2,379 & 2,155 & 1,926 & 1,767 & 1,501 & 1,383 & 1,273 & 1,177 \\
\hline
\end{tabular}

Source: Korea National Statistical Office, each year. 
implemented. There have also been unintended side effects, including the decline of neighbouring villages as residents migrated into the newly constructed villages. In some remote areas, lands were vacated because of a limited demand for housing.

In order to remediate these negative outcomes a village renewal program with an emphasis on the regeneration of existing villages is badly needed. However, there is no specific policy guidances for introducing and implementing such an explicitly dedicated village renewal program. Furthermore, there has not been any close linkage with the national land use planning because there is no specific zoning regulation for rural areas. Without a set of common goals and policies, many projects related to village development have been rather isolated and experimentally undertaken by different government ministries. In this context partnership and cooperation has been very limited. In addition, sustainability issues have not been actively incorporated into village development because natural environment conservation areas, managed by the Ministry of Environment, are not directly connected to the village development planning, carried out by the Ministry of Agriculture, Food and Rural Affairs(MAFRA). Therefore, it is time to integrate village renewal program with the implementation of systematic regional planning as shown in the theoretical framework, as shown in Figure 2 and Figure 3.

\section{4) Local government - initiated village renewal program: Case of Gyeongbuk province}

One province - Gyeongbuk - has attempted to implement a village renewal program(Im et al., 2008). The number of rural villages by administrative unit is 5,113. The number of hamlets totals 11,544 . The rural population in 2006 was approximately 2.6 million and the number of households one million.

Key features of the provincial program include (Im et al., 2008):

Renewal of existing villages can improve rural living environment;

It can lead to facilitate environment and landscape conservation and improvement

Improvement of housing and public infrastructure to retain and/or attract population;

With village renewal planning, rural land can be systematically managed and used; and

It can help to revitalize rural areas by integrating (a) improvements to the built environment, (b) tourism development and (c) natural environment conservation.

Based upon this understanding, the province has engaged in master planning for comprehensive rural village renewal since 2007.

Four categories of villages were defined: (1) "collaborative", (2) "dispersed" (the so called '"outmoded type'" which puts emphasis on the improvement of community facilities, located near urban areas), (3) "ecology", and (4) "landscape" (the so- called "conservation type"' - which emphasizes the utilization of natural environment resources to make the village more eco-friendly and beautiful). They were surveyed and analyzed to classify, prioritize and develop individual master plans. A multi-disciplinary expert group was involved in this planning and preparation process. Additionally village leaders and villagers participated in the survey, discussion meetings, and public hearings. Administrative and technical support and cooperation were provided by local government officials and by the staff of related agencies.

The following stages of program development and implementation can be identified:

Initiate a pilot program by the province;

Identify village characteristics and resources through a survey

Identify the needs of villagers and village leaders;

Coordinate the project alternatives through consultation with experts and public hearings;

Select candidate villages to prioritize them for the development program; and

Craft master plans for the renewal of candidate villages.

Survey results from village leaders reveal that village settlement patterns mainly consist of consolidated (56.2\%), dispersed (20.9\%), and linear (18.4\%) types, which are differentiated by house locations, as shown in Table 4 . In the questionnaire survey, village leaders defined tasks and priorities for improving village landscapes in terms of dealing with derelict properties (40.2\%), development of village parks $(26.8 \%)$, improvement of inner village roads $(11.3 \%)$, and management of streams $(10.3 \%)$, as shown in Table 5. It shows landscape urgently need to be preserved and improved for making villages attractive. 
Table 4 Distribution of village settlement patterns

\begin{tabular}{c|c|c|c|c|c}
\hline Classification & $\begin{array}{c}\text { Consolidate } \\
\text { type }\end{array}$ & $\begin{array}{c}\text { Dispersed } \\
\text { type }\end{array}$ & Line type & Others & Total \\
\hline \hline $\mathrm{f}$ & 113 & 42 & 37 & 9 & 201 \\
\hline$\%$ & 56.2 & 20.9 & 18.4 & 4.5 & 100.0 \\
\hline
\end{tabular}

Table 5 Opinions of tasks and priorities for improving village landscapes

\begin{tabular}{|c|c|c|c|c|c|c|c|c|c|}
\hline $\begin{array}{l}\text { Classificati } \\
\text { on }\end{array}$ & $\begin{array}{c}\text { Arran } \\
\text { gement } \\
\text { of } \\
\text { derelict } \\
\text { properties }\end{array}$ & $\begin{array}{l}\text { Devel } \\
\text { op-ment } \\
\text { of } \\
\text { village } \\
\text { parks }\end{array}$ & $\begin{array}{l}\text { Manag } \\
\text { ement of } \\
\text { streams }\end{array}$ & $\begin{array}{l}\text { Impro } \\
\text { ve-ment } \\
\text { of inner } \\
\text { village } \\
\text { road }\end{array}$ & $\begin{array}{l}\text { Planti } \\
\text { ng at } \\
\text { inter } \\
\text { village } \\
\text { roads }\end{array}$ & $\begin{array}{l}\text { Remod } \\
\text { el-ling of } \\
\text { traditional } \\
\text { houses }\end{array}$ & $\begin{array}{c}\text { House } \\
\text { remodeling }\end{array}$ & Others & Total \\
\hline $\mathrm{f}$ & 78 & 52 & 20 & 22 & 4 & 4 & 13 & 1 & 201 \\
\hline$\%$ & 40.2 & 26.8 & 10.3 & 11.3 & 2.1 & 2.1 & 6.7 & 0.5 & 100.0 \\
\hline
\end{tabular}

Villagers expressed their opinions on the severity of environmental pollution as: severely polluted (8.3\%), generally polluted $(27.2 \%)$, moderate $(35.7 \%)$, generally not polluted $(22.4 \%)$, and not polluted at all $(6.4 \%)$, as shown in Table 6. The main sources of pollution were recognized as water contamination (49.4\%), soil contamination $(23.7 \%)$, air pollution $(9.6 \%)$, noise $(8.2 \%)$ and others $(9.1 \%)$, as shown in Table 7. The villagers' opinions on the importance of rural preservation were: very valuable $(40.0 \%)$, slightly valuable $(22.3 \%)$, moderate $(31.3 \%)$, little value $(5.4 \%)$, and not valuable at all $(1.1 \%)$, as shown in Table 8. It implies that the rural people value a healthy environment and beautiful landscape and they wish to be actively involved in the environment enhancement process

Table 6 Opinions of village environment pollution

\begin{tabular}{c|c|c|c|c|c|c}
\hline Classification & $\begin{array}{c}\text { Severely } \\
\text { polluted }\end{array}$ & $\begin{array}{c}\text { Generally } \\
\text { polluted }\end{array}$ & Moderate & $\begin{array}{c}\text { Generally } \\
\text { not polluted }\end{array}$ & $\begin{array}{c}\text { Not polluted } \\
\text { at all }\end{array}$ & Total \\
\hline \hline $\mathrm{f}$ & 301 & 985 & 1,296 & 814 & 231 & 3,627 \\
\hline$\%$ & 8.3 & 27.1 & 35.7 & 22.4 & 6.4 & 100.0 \\
\hline
\end{tabular}

Table 7 Opinions of highly polluted area

\begin{tabular}{c|c|c|c|c|c|c}
\hline Classification & Water & Soil & Air & Noise & Others & Total \\
\hline \hline $\mathrm{f}$ & 1,508 & 724 & 292 & 250 & 279 & 3,053 \\
\hline$\%$ & 49.4 & 23.7 & 35.7 & 8.2 & 9.1 & 100.0 \\
\hline
\end{tabular}

Table 8 Opinions of ruralness preservation value

\begin{tabular}{c|c|c|c|c|c|c}
\hline Classification & $\begin{array}{c}\text { Highly } \\
\text { valuable }\end{array}$ & Valuable & Moderate & $\begin{array}{c}\text { Little } \\
\text { valuable }\end{array}$ & No valuable & Total \\
\hline \hline $\mathrm{f}$ & 1,438 & 801 & 1,023 & 193 & 3.8 & 3,605 \\
\hline$\%$ & 40.0 & 22.3 & 31.3 & 5.4 & 1.1 & 100.0 \\
\hline
\end{tabular}


with public support.

Based upon the people's needs, spatial context of villages, settlement patterns, natural resources and professional consultation, initial master plans for village renewal could be drafted, as shown in Figure 4. The master plan for village renewal developed under the Gyeongbuk province's pilot program is expected to guide the overall rural village development process. Based on the province's master plan, individual development plans for selected villages are prepared. The villages selected for village renewal will receive support to develop action plans. In the implementation process of the pilot program, some problems were identified, such as no close linkage to farmland legislation, rural development legislation, and the national land use plan, as well as no classification system for prioritizing and characterizing village development.
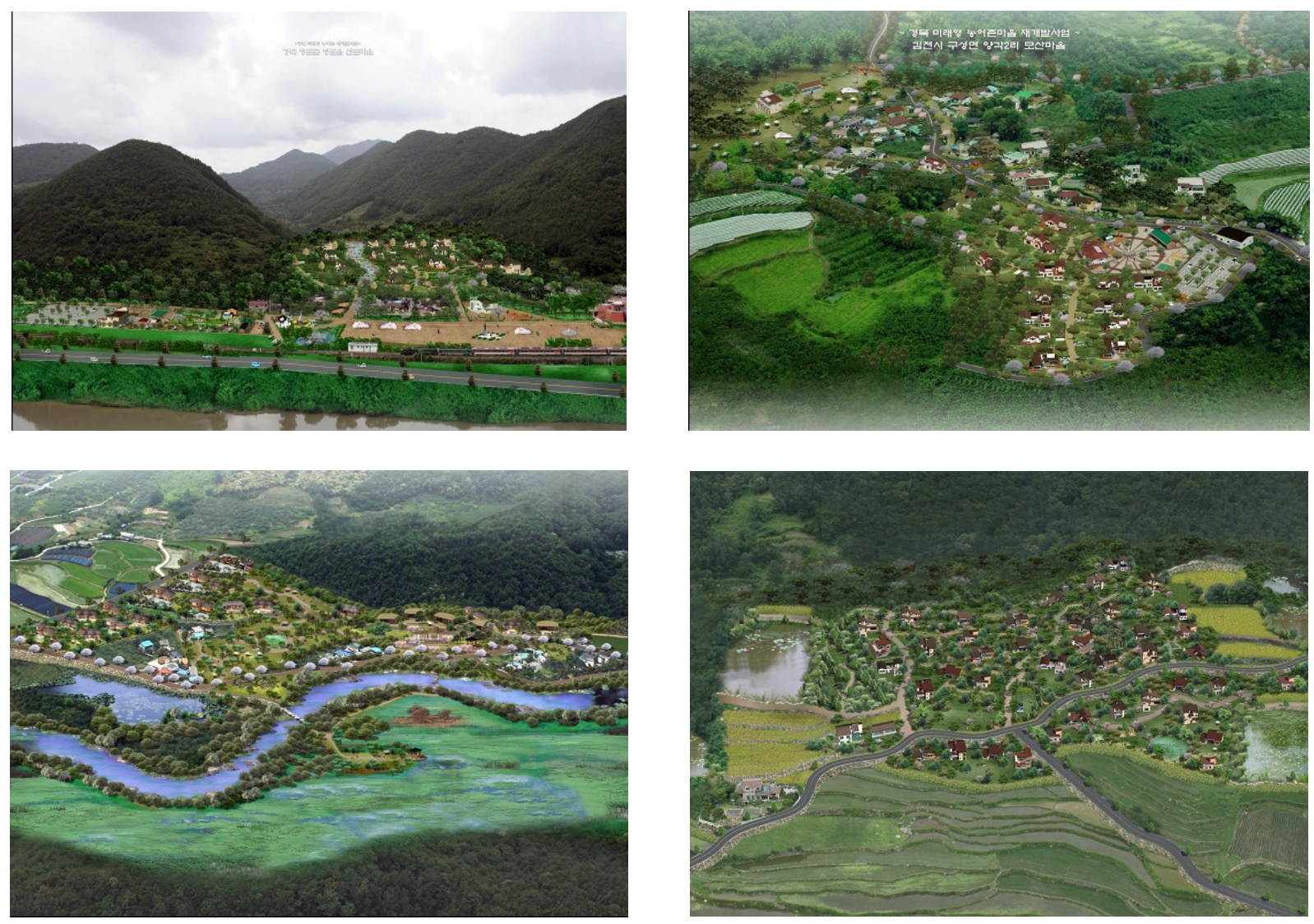

Some lessons for the future development of regional planning for village renewal can be derived from the theoretical framework and the case analysis of Gyeongbuk province.

First, it appears vital that the legal system and regulations related to land use and rural development are revised in order to reflect rural needs. The Farmland Act needs to be amended - it should not only address agricultural productivity, but also rural settlement issues and environmental protection related to agriculture. In this context the rural environmental conservation system also needs to be linked with landscape planning and

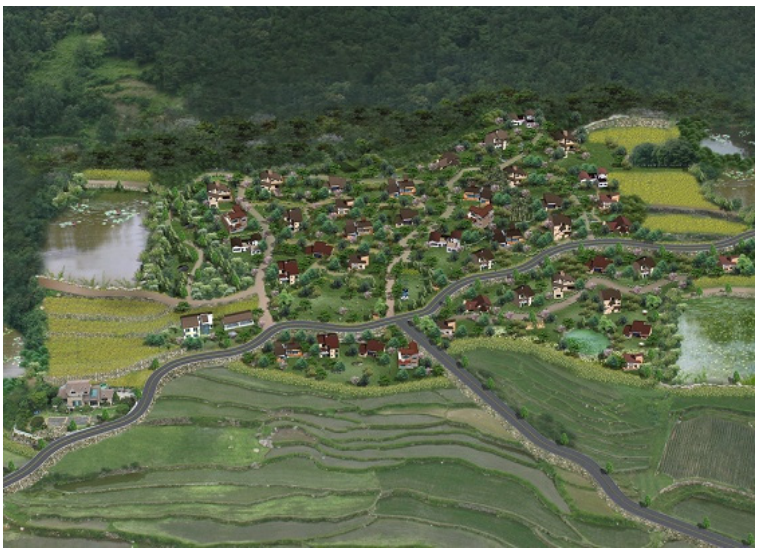

Source: Im et al.(2008)

Figure 4 Bird's-eye views of selected village renewal plans 
management. Additionally public intervention for changing the ownership structure of land also appears to be necessary.

Second, rural areas need to be classified into common categories, such as nature preservation zone, rural housing and settlement zone. Based on this classification, distinct policies can then be developed and applied. Examples are, housing development for repopulation areas, and agrotourism development for environment protection areas(Dammers and Keiner, 2006).

Third, regional planning needs to be coordinated with land use planning and village renewal programs. Based upon the systematic analysis of regional spatial context and resources, land use may have to be changed and rearranged through the planning process.

Fourth, a land consolidation process needs to be initiated to easily acquire lands required for village development (Van Rij and Altes, 2008). It will help to identify the right place for new houses and public infrastructure. Moreover, it is expected that active implementation of land consolidation can foster agricultural restructuring and environmental conservation through targeted exchange of land ownership and leases.

Fifth, specific strategies need to be prepared for the effective implementation of regional planning and village renewal. This includes the following activities:

Put priority on developing key rural villages having established visions;

Base rural regional planning on a needs assessment of existing villages;

Take into consideration urban citizen's' needs;

Introduce and operate a rural land use planning system; and Introduce pilot projects to provide examples of best practices for future generations.

Sixth, in the regional planning process, landscape and environmental aspects must be actively considered. Public investment for village renewal needs to be differentiated by the spatial context, growing or declining area.

\section{Conclusion}

There is broad consensus that sustainable development should guide spatial planning and development including rural planning and village renewal/development.
In this context it is important to understand that environmental resources are crucial for rural regeneration rather than to perceive them as development constraints. Public intervention for sustainable rural development is crucial. Harmonized policies and regulations across the relevant sectoral ministries and different tiers of planning is essential to make rural development and village renewal effective. The village renewal program may be one of the most important projects for fulfilling sustainable rural development, including socioeconomic diversification and environmental sustainability.

Korea's hamlets and villages are waiting for renewal. However, Korea's current legal system presents both limitations and challenges. Public intervention offers new opportunities to rural areas and provides a mechanism for strategic prioritization. Topography will require different strategies for the rural village renewal. The villages losing population need to utilize natural environment and landscape resources through public investment in order to attract exurban people who pursue pastoral lifestyles.

\section{References}

1. Altes, W.K.K., 2008, Evaluating national urban planning: is Dutch planning a success or failure? in New Principles in Planning Evaluation, Urban Planning and Environment, edited by Abdul, K., Hull, A., Miller, D. and Woltjer, J. Aldershot: Ashgate, 221-238.

2. Anton, P.A. The Economic Value of Open Space Implications for Land Use Decisions: Implications for Land Use Decisions, Available at: http://www.embraceopenspace.org/vertical/Sites/\%7B82D BC2D2-DFA6-4A33-879D-A8D2AF1A5804\%7D/upload S/\%7B3A54EEAC-BD55-4A8F-B49F-EC58D5CD328F\% 7D.PDF [accessed: 3 September 2008].

3. Bavarian State Ministry for Agriculture and Forestry, 2003, Landscape Management: Village Renewal, Land Consolidation, Land Development Regional, Bavarian State Ministry for Agriculture and Forestry.

4. Borough Council of King's Lynn \& West Norfolk, 1998, King's Lynn \& West Norfolk Local Plan: A Summary Guide, Borough Council of King's Lynn \& West Norfolk. 
5. Choi, W., 2004, Farmland Consolidation in Korea, Paper to the Symposium on Modern Land Consolidation, Volvic, France, 10-11 September 2004.

6. Choi, Y.K., 2004, Linking planning system between spatial development plan and environment plan toward sustainable development, Ecological Issues in a Changing World - Status, Response and Strategy, edited by Hong, S.K. et al. Kluwer Academic Publishers, Printed in the Netherlands, 263-299.

7. Dammers, E. and Keiner, M., 2006, Rural development in Europe: trends, challenges and prospects for the future, disP, 166(3), 5-15.

8. Doitchinova, J., 2005, Multifunctional agriculture as opportunity for rural development, Trakin Journal of Sciences, 3 (7), 41-43.

9. Dunford, M., 2008, Regional Development Models, Available at: http://www.geog.susx.ac.uk/research/eggd/ege/pdf/models rd.pdf [accessed: 1 September 2008].

10. FAO, 2008, Opportunities to Mainstream Land Consolidation in Rural Development Programmes of the European Union, Rome: FAO.

11. FIG et al., The Munich Statement on land consolidation as a tool for rural development in CEE/CIS countries, Available at:

http://www.landentwicklung-muenchen.de/cd_ceec_confe rence/3_results_of_the_conference/3_munich_statement /munich_statment_logos.pdf [accessed: 8 September 2008].

12. Gur, M., Cagdas, V. and Demirei, Z., 2003, Land Consolidation As a Tool of Rural Sustainable Development, Paper to the 2nd FIG Regional Conference, Marrakech, Morocco, December 2-5, 2003.

13. Heins, S., 2004, Rural living in the city and countryside: demand and supply in the Netherlands, Journal of Housing and Built Environment, 17(4), 391-408.

14. Hite, J., 1999, The Thunen Model As a Paradigm for Rural Development, Available at: http://www.strom.clemson.edu/opinion/hite/thunen.html [accessed: 13 September 2008].

15. Hong, S.K., Song, I.S., Byun, B., Yoo, S. and Nakagoshi, N., 2005, Applications of biotope mapping for spatial environmental planning and policy: case studies in urban ecosystems in Korea, Landscape and Ecological Engineering, 1(2), 101-112.

16. Hrebiniak, L.G. and Joyce, W.F., 1985, Organizational adaptation: strategic choice and environmental determinism", Administrative Science Quarterly, 30, 336-349.

17. Hwang, H.C., 1999, Rural Land Use Planning, Anseng: Anseong University Press.

18. Im, S.B. et al., 2008, A Study on the Masterplan of Rural Village Redevelopment in Gyeongbuk Korea, Gyeongbuk Province, Uiwang: Korea Rural Community Corporation.

19. Jervell, A.M. and Jolly, D.A., 2003, Beyond Food: Towards a Multifunctional Agriculture, Oslo: Norwegian Agricultural Economics Research Institute.

20. Kates, R.W., Parris, T.M. and Leiserowitz, A.A., 2005, What is sustainable development? goals, indicators, values, and practice, Environment: Science and Policy for Sustainable Development, 47 (3), 8-21.

21. Magel, H., 2003, LandPolicy and Land Management in Germany, Available at: http://www.landentwicklung-muenchen.de/mitarbeit/mage 1/aufsaetze_vortraege_2003/uni_melb-06022003.pdf [accessed: 7 October 2008].

22. Magel, H., 2008, Village Renewal in Germany: Objectives, Measures, Success, Available at: http://www.landentwicklung-muenchen.de/mitarbeit/mage 1/aufsaetze_englisch/village.htm[accessed: 5 October 2008].

23. Ministry of Land, Infrastructure, and Transportation, 2012, Annual Report on National Land Use.

24. Morimoto, Y., 2004, Ecological dynamics of urban-rural landscapes - the need for landscape planning that considers the biodiversity in Japan", Ecological Issues in a Changing World - Status, Response and Strategy, edited by Hong, S.K. et al. Kluwer Academic Publishers, Printed in the Netherlands, 325-336.

25. Nemes, G., 2005, Integrated Rural Development: The Concept and Its Operation, Budapest: Institute of Economics Hungarian Academy of Sciences.

26. OECD, 1999, Cultivating Rural Amenities, Paris: OECD.

27. Ohm, B.W., 2001, Required Elements of a Local Comprehensive Plan, Wisconsin: Board of Regents of 
the Universityof Wisconsin System.

28. Pal, A., 2008, Planning from the Bottom Up: Democratic Decentralisation in Action, Delft: Delft University of Technology.

29. Reinke, M., 2005, Urban planning and SEA, Implementing Strategic Environmental Assessment, edited by Schmidt, M., 571-584.

30. Roberts, S., 2002, Key Drivers of Economic Development and Inclusion in Rural Areas: Initial scoping study of the socio-economic evidence base for DEFRA, Report researched and produced for DEFRA.

31. Scholles, F. and Haaren, C. von, 2005, Co-ordination of SEA and landscape planning, Implementing Strategic Environmental Assessment, edited by Schmidt, M.., 557-570.

32. Studsholt, A., 2000, Experience of strategic environmental assessment in regional land use planning in North Jutland County in Denmark, Regional Development Programmes and Integration of Environmental Issues: the Role of Strategic Environmental Assessment, Workshop Proceedings, edited by Hilding, T., 43-45.

33. Terluin, I., Roza, P., Berkhout, P., Godeschalk, F.and Betgen, M., 2006, Comparative Analyisis of EU Rural Development Policy in Central and Eastern European Countries and the Netherlands, The Hague: The Agricultural Economics Research Institute (LEI).
34. U.S. Interagency Working Group on Sustainable Development Indicators Washington D.C., 2001, Sustainable Development in the United States: A Experimental Set of Indicators, Available at: http://www.sdi.gov/lpBin22/lpext.dll/Folder2/Infobase/1?f $\mathrm{n}=$ main-j.htm\&f=templates $\& 2.0$ [accessed: 9 November 2008].

35. Van den Brink, A. and Molema, M., 2008, The origins of Dutch rural planning: a study of the early history of land consolidation in the Netherlands, Planning Perspectives,23 (October),427-453.

36. Van Rij, E. and Altes, W.K.K., 2008, The merits of outmoded planning instruments for improving metropolitan green areas: the midden-delfland approach, Planning Theory \& Practice, 9(3), 345-362.

37. Waterhout, B., 2008, The Institutionalisation of European Spatial Planning, Delft: Delft University of Technology.

38. WWF, LUPG and SNM, 2005, Rural Development Environmental Programming Guidelines: A Manual Based on the Findings of the Europe's Living Countryside (ELCo) project, WWF, LUPG and SNM.

접 수 일: (2013년 9월 12일)

수 정 일: (1차: 2013년 9월 27일)

게재확정일: (2013년 9월 27일)

- 3인 익명 심사필 